\title{
DETERMINATION OF THE CRITICAL FRACTION OF SOLID DURING THE SOLIDIFICATION OF A PM-CAST ALUMINIUM ALLOY
}

\author{
DOLOČANJE KRITIČNEGA DELEŽA STRJENE FAZE MED \\ STRJEVANJEM V PM ULITE ALUMINIJEVE ZLITINE
}

\author{
Ramazan Kayikci' ${ }^{1}$, Murat Colak ${ }^{2}$, Selcuk Sirin', Engin Kocaman', Neset Akar ${ }^{3}$ \\ ${ }^{1}$ Sakarya University, Faculty of Technology, Dept. of Met. Mat. Eng., Sakarya, Turkey \\ ${ }^{2}$ Bayburt University, Faculty of Eng., Dept. of Mat. Sci. and Nanotech. Eng., Bayburt, Turkey \\ ${ }^{3}$ Gazi University, Faculty of Technology, Dept. of Met. Mat. Eng., Ankara, Turkey \\ rkayikci@sakarya.edu.tr \\ Prejem rokopisa - received: 2014-10-20; sprejem za objavo - accepted for publication: 2014-11-27
}

doi:10.17222/mit.2014.266

\begin{abstract}
During the solidification of aluminium alloys, a flow of the interdendritic liquid through the mushy zone plays an important role in the feedability and shrinkage-driven porosity formation. Therefore, for almost all the studies about casting modelling, a good knowledge of the mushy-zone behaviour is necessary.

In this study, the limit of the mushy-zone permeability for permanent-mould (PM)-cast aluminium alloys was investigated. A novel experimental technique was developed to quantify the value of the critical fraction of solid (CFS) at which the interdendritic feeding stops. Grain-refined and non-grain-refined aluminium alloys were used to evaluate the effect of the grain size on the CFS limit of both the non-grain-refined and fully grain-refined alloys. Three different initial mould temperatures were used to find if the mould temperature has any effect on the feeding of a casting. Alloys of varying solidification intervals were also used to determine the critical fraction of solid (CFS) for the feeding limit of solidifying castings.

The results showed that the CFS values for solidifying aluminium alloys may vary from $34 \%$ to $57 \%$ depending on the casting conditions. The results also showed that for A356 aluminium-alloy castings the CFS value is not an alloy property, yet it significantly depends on the parameters such as the grain refinement and the modification of eutectic silicon.

Keywords: critical fraction of solid, mushy-zone permeability, PM casting
\end{abstract}

Med strjevanjem aluminijevih zlitin ima tok meddendritne taline skozi testasto področje pomembno vlogo pri napajanju in nastajanju poroznosti zaradi krčenja. Zato je skoraj v vseh modelih ulitkov potrebno dobro poznanje vedenja testastega področja.

$\mathrm{V}$ tej študiji je bila iskana meja prepustnosti testastega področja pri aluminijevih zlitinah, ulitih v stalne forme (PM). Razvita je bila nova eksperimentalna tehnika za oceno kritičnega deleža strjene faze (CFS), pri kateri se meddendritno napajanje ustavi. Uporabljene so bile aluminijeve zlitine $\mathrm{z}$ udrobnjenimi in neudrobnjenimi zrni za oceno vpliva velikosti zrn na mejno CFS pri obeh vrstah zlitin. Izmerjene so bile tri različne temperature kokil, da bi ugotovili, ali temperatura kokile vpliva na napajanje ulitka. Uporabljene so bile tudi zlitine z različnim intervalom strjevanja, da bi ugotovili kritičen delež trdne faze (CFS), ki pomeni mejo napajanja pri strjevanju ulitkov.

Rezultati so pokazali, da vrednosti CFS variirajo med $34 \%$ in $57 \%$, odvisno od razmer pri ulivanju. Rezultati so tudi pokazali, da pri ulitkih iz aluminijeve zlitine A356 vrednost CFS ni odvisna samo od zlitine, temveč je zelo odvisna od parametrov, kot sta zmanjšanje zrn in modifikacija evtektičnega silicija.

Ključne besede: kritičen delež trdne faze, prepustnost testastega področja, ulivanje v stalne forme (PM)

\section{INTRODUCTION}

The solidification of aluminium alloys generally starts with dendrites of a aluminium and they continue to grow into a coherent network. With the progress of solidification, several intermetallics might precipitate and the solidification usually completes with one or more eutectic phases. ${ }^{1}$ While the solidification continues, the viscosity of liquid aluminium alloys increase with a decrease in the fluidity. During the solidification, aluminium alloys pass through a long mushy region during which the liquid requirement for a contraction of solidifying dendrites can be compensated with a flow of the interdendritic liquid. ${ }^{2}$ These mechanisms continue until a certain stage of the solidification in the mushy zone. Dendrite coherency is established in a later stage and the dendrite network gains some rigidity which becomes resistant against the flow of the interdendritic liquid. ${ }^{3}$ This phenomenon continues until the liquid flow stops completely due to the blockage of the growing solid dendrites. ${ }^{3}$ In the literature about casting solidification, this stage of the solidification is defined as either 'the critical fraction of solid' or 'the critical fraction of liquid'. ${ }^{4}$

At the critical fraction of the solid (CFS) stage, if there is still a need for the liquid flow for feeding the solidifying liquid, a pressure drop is created due to the resistance to the liquid flow. If this negative pressure in the mushy zone cannot be balanced by the flow of the liquid due to the dendrite blockage it may lead to some shrinkage porosity. ${ }^{5}$ Shrinkage cavities that can often be seen in casting processes are typical examples of this porosity. Today high-performance technology requires 
high-quality and light-section castings and therefore cannot even tolerate micro-porosity ${ }^{6}$. To avoid the formation of micro- and macro-porosities within the critical sections of cast parts, a variety of 3D casting-modelling software packages, often referred to as casting simulation packages, have been used during the design stages of casting processes. Since the CFS point is practically the end of the feeding action within a mushy region, it has been used as one of the most critical boundary conditions in all the commercial casting-simulation software packages. Therefore, to model aluminium casting processes with different alloys and cooling-solidification conditions, a good knowledge about the critical fraction of solid (CFS) is necessary.

In this study, using commercial A356 aluminium casting alloys, the CFS point of the mushy zone was investigated. Permanent mould castings with three different alloy conditions, namely, the as-cast, the grainrefined, and the grain-refined and modified conditions were used. Casting-simulation techniques, X-ray radiography, the Archimedes density measurement and metallographic techniques were also employed.

\section{EXPERIMENTAL WORK}

The experimental part of the present study is twofold. In the first part an A356 aluminium alloy was cast in a steel mould and the resulting shrinkage was examined for varying casting conditions. In the second part, the casting and mould geometries were modelled using the SOLIDCast 3D casting-simulation software. Finally, the amounts of the shrinkage porosity obtained from the actual castings were compared with the results from the computer modelling and the feeding threshold value (the critical fraction of solid) was determined for each casting condition.

The casting geometry and the solidified cast part within the mould are shown in Figures $\mathbf{1 a}$ and $\mathbf{1 b}$, respectively. The casting geometry was specially designed to obtain two thick sections connected to each other with a narrow feeding neck to create an insufficient feeding path so that it could produce a measurable
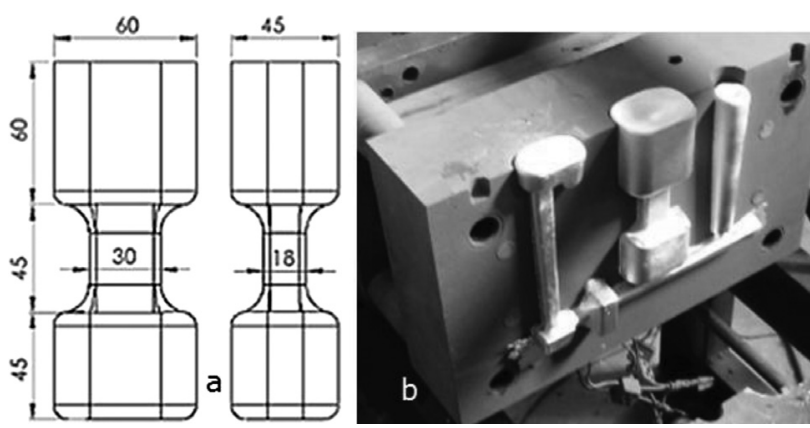

Figure 1: a) Casting geometry, b) solidified casting within a permanent mould

Slika 1: a) Geometrija ulitkov, b) strjen ulitek v stalni kokili amount of the shrinkage porosity at the bottom part of the casting, used for comparison and evaluation.

A chemical analysis of the A356 alloy was carried out with a Foundry-Master optical emission spectrometer before and after each addition to the master alloy as shown in Table 1. Primary ingots of $8 \mathrm{~kg}$ were melted in a $\mathrm{SiC}$ crucible in a bell-type electric-resistance-heated furnace. The alloy was degassed with dry nitrogen at 720 ${ }^{\circ} \mathrm{C}$ for 6 min before being cast into a steel mould which was preheated to $300{ }^{\circ} \mathrm{C}$. The casting process was repeated and followed by an addition of an Al5Ti1B-type grain refiner or an Al-10Sr modification of the master alloy. The castings were radiographically tested on both sides to check whether any shrinkage porosity had occurred. Their upper and bottom parts were separated by cutting them apart from the top of the narrow neck and the cast density of the bottom parts was measured, using the Archimedes system of weighing the parts in air and in water. Finally, the castings were sectioned along the vertical axis to reveal any shrinkage in the central regions of the castings.

Table 1: Chemical composition of the A356 alloy used in the experiments (Al balance), w/\%

Tabela 1: Kemijska sestava zlitine A356, uporabljene pri preizkusih (osnova je Al), w/\%

\begin{tabular}{|l|c|c|c|c|c|c|c|}
\hline \multicolumn{1}{|c|}{ Elements } & $\mathrm{Fe}$ & $\mathrm{Si}$ & $\mathrm{Cu}$ & $\mathrm{Mn}$ & $\mathrm{Mg}$ & $\mathrm{Ti}$ & $\mathrm{Sr}$ \\
\hline As-cast & 0.35 & 6.9 & 0.1 & 0.35 & 0.38 & 0.03 & 0 \\
\hline TiB modified & 0.35 & 6.8 & 0.1 & 0.34 & 0.36 & 0.12 & 0 \\
\hline Sr modified & 0.35 & 6.82 & 0.1 & 0.3 & 0.3 & 0.1 & 0.08 \\
\hline
\end{tabular}

A commercial 3D casting-simulation package, SOLIDCast, was used for modelling the castings. The system solves the Fourier heat-transfer equation with the finite-difference method and calculates the volume change within the casting with respect to the temperature. It assumes that the feeding takes place under the gravity effect and the volume of the total final shrinkage

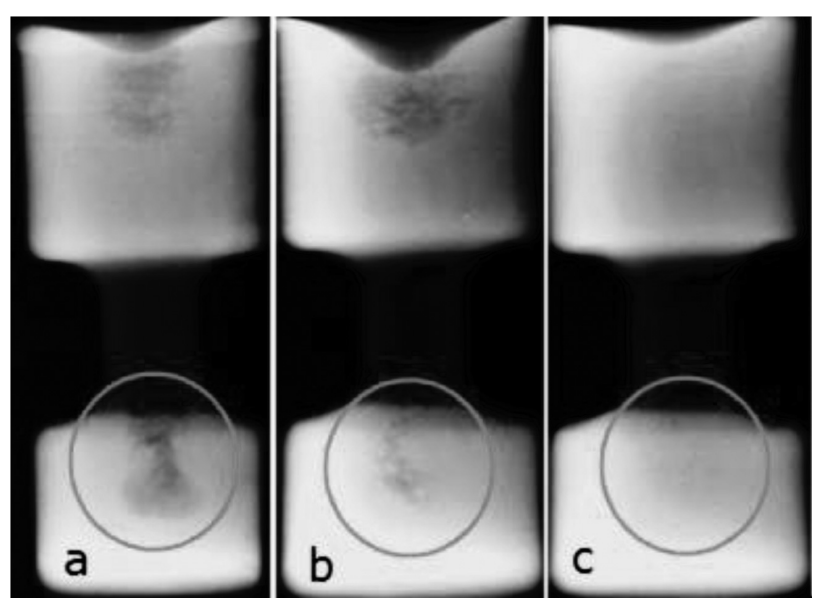

Figure 2: Scanned view of the radiographic test films of A356 castings: a) as cast, b) with added $\mathrm{TiB}$, c) with added $\mathrm{TiB}+\mathrm{Sr}$

Slika 2: Skenirani posnetki filmov rentgenskih posnetkov ulitkov iz A356: a) lito stanje, b) dodan $\mathrm{TiB}, \mathrm{c}$ ) dodan $\mathrm{TiB}+\mathrm{Sr}$ 


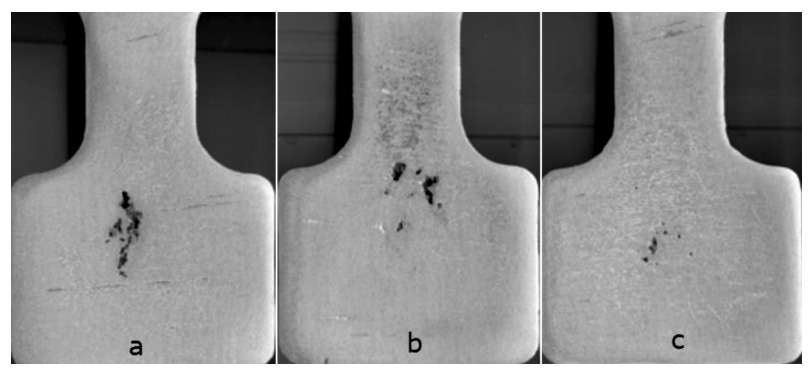

Figure 3: Cross-sections of A356 castings: a) as cast, b) with added $\mathrm{TiB}, \mathrm{c})$ with added $\mathrm{TiB}+\mathrm{Sr}$

Slika 3: Prerez ulitka iz A356: a) lito stanje, b) dodan TiB, c) dodan $\mathrm{TiB}+\mathrm{Sr}$

pores is equal to the volume of the unfed contracted liquid metal. The system can allow the feed-liquid movement as long as the feeding path is open, i.e., the fraction of solid (FS) is below the critical value in the mushy zone.

\section{RESULTS AND DISCUSSION}

A set of the radiographic test results representing the as-cast, TiB-modified and $\mathrm{TiB}+\mathrm{Sr}$-modified castings is shown in Figure 2. The potential shrinkage areas in the bottom sections of the castings are highlighted with circles. Dark smoky marks in the circled areas indicate the shrinkage porosity. The largest shrinkage occurred in the casting in the as-cast condition indicating the lowest feeding action of this particular casting. This was associated with a shorter CFS time due to an early blockage of coarser dendrites. On the other hand, the casting that was fully grain refined and modified with an addition of $\mathrm{TiB}+\mathrm{Sr}$ revealed the smallest amount of the shrinkage porosity. This showed that the longest feeding action took place during the solidification. Only the grainrefined casting (TiB-modified only) showed an intermediate shrinkage porosity. These results are in good

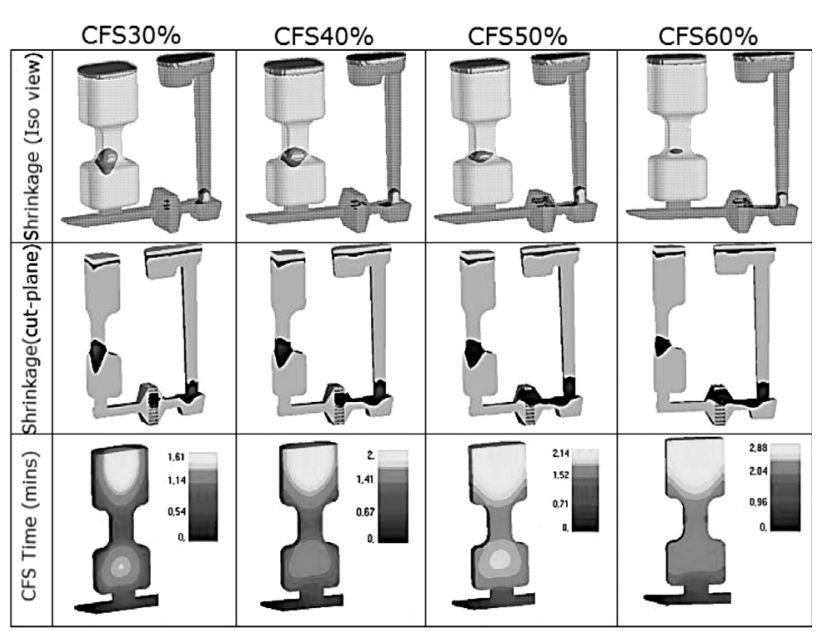

Figure 4: Representative results obtained with a casting simulation with four different CFS conditions

Slika 4: Značilni rezultati, dobljeni s simulacijo ulivanja pri štirih različnih CFS-razmerah agreement with the report on the grain refinement of an aluminium alloy by Birol. ${ }^{7}$

Figure 3 shows macrostructures of the cross-sections of the castings. The shrinkage patterns of the castings reveal characteristics similar to the $\mathrm{X}$-ray radiography pattern shown in Figure 2. The percentages of the shrinkage porosity of the castings were determined by subtracting their measured Archimedes densities from the theoretical density of a well-fed PM cast of the A356 alloy. The results obtained from the simulations of the castings are shown in Figure 4. This figure shows that increasing the CFS values of the castings resulted in longer feeding times as the time required to reach a given CFS value of the mushy zone also increased. Modelled porosities were obtained directly from the simulation results. These values are given in Table 2 . The corresponding CFS values for different casting conditions are also given in Table 2. A number of simulations were run to change the CFS point of a casting as a boundary condition from $30 \%$ to $70 \%$ and their resulting porosity values were compared with the measured porosity values of the actual castings. Determination of the actual CFS value of each casting was carried out by comparing the measured and modelled densities. When a close match was obtained between the two, the corresponding value of the CFS that was already used as an input boundary condition in that particular casting simulation was assumed to be the right value of the CFS. As seen in Table 2, the lowest CFS value of $34 \%$ and the shorter feeding time were obtained for the PM-cast A356 alloy. The CFS value significantly increases with the grain refinement achieved with the $\mathrm{TiB}$ addition to the melt, reaching $52 \%$. The modification of the eutectic silicon with $\mathrm{Sr}$ provides further improvement, causing the CFS to rise to $57 \%$.

Table 2: Comparison of measured and modelled porosity fraction of the castings with their CFS values

Tabela 2: Primerjava izmerjenih in z modelom določenih deležev poroznosti ulitkov z vrednostmi CFS

\begin{tabular}{|c|c|c|c|}
\hline $\begin{array}{c}\text { Experimental } \\
\text { castings }\end{array}$ & \multicolumn{3}{|c|}{ Modelling } \\
\hline $\begin{array}{c}\text { Alloy } \\
\text { condition }\end{array}$ & $\begin{array}{c}\text { Measured } \\
\text { porosity (\%) }\end{array}$ & $\begin{array}{c}\text { Calculated } \\
\text { porosity (\%) }\end{array}$ & CFS value (\%) \\
\hline As-cast & 2.25 & 2.22 & 34 \\
\hline TiB modified & 1.83 & 1.82 & 52 \\
\hline $\begin{array}{c}\text { TiB }+\mathrm{Sr} \\
\text { modified }\end{array}$ & 1.36 & 1.36 & 57 \\
\hline
\end{tabular}

\section{CONCLUSIONS}

- An experimental casting technique coupled with a casting simulation was studied to determine the CFS values of the commercial A356 alloy in the as-cast, TiB-modified and TiB + Sr-modified conditions.

- The results showed that the CFS point of the mushy zone is not a constant value as it might vary significantly with different conditions of the cast alloy. 
- The lowest CFS value of $34 \%$ was obtained for the as-cast A356 alloy, while it increased up to $57 \%$ with a grain refinement and modification of the eutectic silicon by adding $\mathrm{TiB}+\mathrm{Sr}$ to the alloy.

\section{Acknowledgement}

The authors are grateful to The Scientific and Technological Research Council of Turkey (TÜBİTAK) for providing a research grant to the $112 \mathrm{M} 422$ project.

\section{REFERENCES}

${ }^{1}$ M. C. Flemings, Solidification Processing, McGraw-Hill, New York 1974

${ }^{2}$ B. O. Danylo, Ö. N. Doğan, An examination of effects of solidification parameters on permeability of a mushy zone in castings, Journal of Materials Science, 43 (2008), 1471-1479, doi:10.1007/ s10853-007-2325-Z

${ }^{3} \varnothing$. Nielsen, S. O. Olsen, Experiment for Quantification of Feedability and Permeability in Industrial Aluminium Alloys, International Journal of Cast Metals Research, 19 (2006) 1, 32-37, doi:10.1179/ 136404606225023336

${ }^{4}$ D. Sun, S. V. Garimella, Numerical and Experimental Investigation of Solidification Shrinkage, Numerical Heat Transfer, Part A: Applications, 52 (2007) 2, 145-162, doi:10.1080/1040778060 1115079

${ }^{5}$ Ch. Pequet, M. Gremaud, M. Rappaz, Modelling of Microporosity, Macroporosity, and Pipe Shrinkage Formation during the Solidification of Alloys Using a Mushy-Zone Refinement Method: Applications to Aluminum Alloys, Metallurgical and Materials Transactions, 33A (2002) 7, 2095-2106, doi:10.1007/s11661-002-0041-5

${ }^{6}$ M. Tiryakioğlu, J. Campbell, Guidelines for Designing Metal Casting Research: Application to Aluminium Alloy Castings, International Journal of Cast Metals Research, 20 (2007) 1, 25-29, doi:10.1179/136404607X186509

${ }^{7}$ Y. Birol, Grain Refinement in Aluminium Shape Casting, Proc. of the 3rd Int. Aluminium Conference, Arak, Iran, 2012, 1-12 